\title{
PENGARUH PARTISIPASI SISWA DALAM EKSTRAKURIKULER PRAMUKA TERHADAP PERILAKU PROSOSIAL SISWA SEKOLAH DASAR
}

\author{
Frista Kenanga \\ e-mail: ade.dwi.utami@gmail.com \\ Alumni PG PAUD Universitas Negeri Jakarta
}

\begin{abstract}
Abstrak: Penelitian ini bertujuan untuk memperoleh data empiris mengenai pengaruh partisipasi siswa dalam ekstrakurikuler terhadap perilaku prososial siswa kelas III SD. Penelitian ini dilaksanakan di SDN 09 dan SDN 11 Lubang Buaya, Jakarta Timur pada bulan Mei-Juni 2013. Metode penelitian menggunakan Expost Facto. Sampel penelitian adalah siswa kelas III SDN 09 Pagi dan 11 Pagi Lubang Buaya, Jakarta Timur yang dibagi menjadi kelompok coba dan kelompok pembanding. Teknik pengambilan sampel menggunakan Cluster Random Sampling. Teknik pengumpulan data yang digunakan yaitu angket dan observasi terstruktur. Teknik analisis penelitian menggunakan uji normalitas dan uji homogenitas. Teknik pengujian hipotesis menggunakan uji-t. Hasil pengujian hipotesis menunjukkan thitung $=30,1>\operatorname{ttabel}=1,686$, yang artinya $\mathrm{H} 0$ ditolak dan Ha diterima. Dengan demikian, kesimpulan yang diperoleh adalah perilaku prososial pada siswa kelompok coba lebih tinggi dibanding perilaku prososial pada siswa kelompok pembanding, yang artinya pengaruh signifikan partisipasi siswa dalam ekstrakurikuler pramuka terhadap perilaku prososial siswa kelas III di Kelurahan Lubang Buaya, Jakarta Timur.
\end{abstract}

Kata kunci: perilaku prososial, partisipasi siswa, ekstrakurikuler pramuka

\section{EFFECT OF THE STUDENT PARTICIPATION IN SCOUT EXTRACURRICULUM ON THE PROSOCIAL BEHAVIOR OF PRIMARY SCHOOL STUDENTS}

\begin{abstract}
This research is aimed to get empirical data about the influence of student's participation in scout toward student's 3rd grade elementary school prosocial behavior. The research was conducted at SDN 09 and 11 Lubang Buaya, East Jakarta on May until June 2013. This research used Expost Facto method. The sample in this research is amount 40 students of 3rd grade in SDN 09 and 11 Lubang Buaya, East Jakarta, there are 20 students as the experiment group and 20 students as the control group. The sample of this research was taken by using cluster random sampling. Data collection technique in this research used questioner and observation. The technique for data analysis used Liliefors test and Fisher test. The technique for hypothesis used $t$-test. The t-test result showed tcount $=30,1>$ ttable $=1,686$, that means $\mathrm{HO}$ was rejected and Ha was accepted. Thus, the conclusion is the student's prosocial behavior in experiment group is higher than the student's prosocial behavior in control group, that showed the student's participation in scout has significant effect on student's 3rd grade elementary school prosocial behavior in Lubang Buaya, East Jakarta.
\end{abstract}

Keywords: prosocial behavior, student's participation, scout extracurriculum

\section{PENDAHULUAN}

Masa usia dini merupakan masa yang penting dalam kehidupan seorang anak. Pada masa ini terjadi proses perkembangan pada anak yang berjalan secara bertahap seiring dengan bertambahnya usia anak. Dalam proses tersebut akan terjadi perubahanperubahan yang dapat dilihat pada diri anak, salah satunya perubahan perilaku.
Terdapat beberapa aspek perkembangan pada manusia, salah satunya yaitu perkembangan sosial. Dalam perkembangan sosial, terdapat perilaku yang diharapkan muncul pada anak, yaitu perilaku prososial yang merupakan tindakan-tindakan sosial positif untuk menguntungkan orang lain baik secara fisik maupun psikis. 
Perilaku prososial diharapkan muncul pada anak, karena perilaku ini berperan penting dalam kehidupan sosial seorang anak. Sebuah penelitian mengungkapkan bahwa anak yang berperilaku prososial relatif lebih diterima dan memiliki hubungan pertemanan sebaya yang lebih baik dari anak yang perilaku prososialnya lebih rendah (Knafo \& Folmin, 2006). Jadi, perilaku prososial pada anak akan membantu anak itu sendiri dalam kehidupan sosialnya, di mana anak menjadi lebih mudah diterima dalam pertemanan dan baiknya hubungan pertemanan yang mereka jalani.

Namun pada kenyataanya, perilaku prososial pada anak telah mengalami penurunan. Fenomena menipisnya perilaku prososial telah terjadi dikalangan anak-anak (Meita, 2013). Perilaku prososial dan perkembangannya pada anak merupakan isu yang dapat digambarkan mengalami peningkatan perhatian dalam beberapa tahun ini (Maria, dkk, 2005). Berdasarkan hal tersebut, perilaku prososial dan perkembangannya pada anak, mendapatkan perhatian khusus selama beberapa tahun terakhir.

Perilaku prososial dipengaruhi oleh faktor biologis dan faktor lingkungan. Faktor lingkungan seperti keluarga, pertemanan sebaya, serta sekolah, merupakan faktor yang dapat dimaksimalkan untuk mendorong perilaku prososial pada anak. Selain di rumah, anak pada usia kelas III Sekolah Dasar, banyak menghabiskan waktu di sekolah. Lingkungan sekolah bagi anak usia tersebut merupakan tempat di mana ia bisa belajar dan berkesempatan untuk mengembangkan berbagai potensi diri karena di sekolah terjadi proses pembelajaran, baik pembelajaran di dalam maupun luar jam pelajaran.

Pembelajaran di luar jam pelajaran berfokus untuk membantu mengembangkan potensi anak. Pembelajaran ini dapat berbentuk kegiatan ekstrakurikuler yang bertujuan untuk mengembangkan potensi peserta didik, sesuai dengan kebutuhan, potensi, bakat dan juga minat mereka. Ekstrakurikuler ini dilaksanakan untuk menyeimbangkan pembelajaran di dalam jam pelajaran. Salah satu ekstrakurikuler wajib yang ada di tingkat Sekolah Dasar, yaitu ekstrakurikuler pramuka. Di kelas III SD, anggota pramuka berada pada tingkat Pramuka Siaga.

Partisipasi siswa dalam ekstrakurikuler pramuka memberikan banyak peluang untuk mendorong perilaku prososial siswa. Banyak hal dalam ekstrakurikuler pramuka yang dapat memberikan kesempatan untuk berperilaku prososial karena ekstrakurikuler pramuka dilaksanakan dalam metode berkelompok yang menuntut anak untuk dapat lebih berperilaku prososial.
Sistem yang digunakan dalam ekstrakurikuler pramuka adalah sistem beregu. Hal tersebut dimaksudkan para agar anggota pramuka memperoleh kesempatan belajar memimpin dan dipimpin, mengatur dan diatur, berorganisasi, memikul tanggungjawab, serta bekerja dan bekerjasama dalam kerukunan. Dengan kata lain, sistem beregu dalam ekstrakurikuler pramuka memberikan kesempatan bagi siswa untuk mengembangkan tindakan-tindakan kerjasama yang baik dalam berorganisasi maupun bekerja, di mana kerjasama juga merupakan bentuk dari perilaku prososial.

Kegiatan dalam ekstrakurikuler pramuka juga mendorong siswa untuk lebih berperilaku prososial, seperti berkemah. Dalam berkemah, siswa hidup sementara bersama anggota pramuka lainnya. Pada saat itulah siswa dituntut untuk menyesuaikan diri dengan berperilaku prososial, seperti menolong sesama anggota, kebersamaan untuk saling menjaga anggota, serta saling berbagi manakala hal tersebut dibutuhkan. Tindakan-tindakan tersebut merupakan pencerminan dari perilaku prososial yang bisa dikembangkan dalam berkemah.

Selain berkemah, di dalam ekstrakurikuler pramuka juga terdapat kegiatan sosial, seperti kegiatan bakti sosial yang mencerminkan perilaku prososial. Kegiatan ini ditunjukkan untuk menumbuhkan kesadaran siswa untuk berbagi pada sesama. Hal yang paling sering dilakukan dalam bakti sosial ini misalnya menyumbang untuk orang lain yang membutuhkan. Dengan adanya contoh yang diberikan, diharapkan siswa juga melaksanakannya dalam kegiatan seharihari.

Berdasarkan hal-hal yang telah dijabarkan di atas, dapat dilihat bahwa perilaku prososial pada anak begitu penting dalam kehidupan sosial anak, khususnya untuk anak kelas III SD. Salah satu kegiatan yang dapat memberikan kesempatan bagi anak untuk berperilaku prososial, yaitu kegiatan ekstrakurikuler pramuka. Semakin anak berpartisipasi dalam ekstrakurikuler pramuka, semakin besar kesempatan yang diperoleh anak untuk mengembangkan perilaku prososialnya, sehingga dapat menjadi jawaban atas permasalahan menipisnya perilaku prososial pada anak khususnya di tingkat kelas III Sekolah Dasar.

\section{Perilaku Prososial}

Perilaku prososial merupakan salah satu aspek yang penting dalam perkembangan sosial seseorang, yaitu kemampuan untuk berinteraksi dengan orang lain dengan cara prososial (Puckett, 2004: 99). Dapat dikatakan bahwa perilaku prososial merupakan aspek yang penting di perkembangan sosial yang perlu 
berkembang dengan baik dalam diri individu.

Perilaku prososial dilakukan untuk menguntungkan orang lain. Perilaku prososial merupakan tingkah laku yang dilakukan secara sukarela, menguntungkan orang lain tanpa antisipasi rewards eksternal (Bartal dalm Desmita, 2009: 236). Perilaku prososial ada tanpa pengaharapan akan imbalan bagi yang telah menolong.

Perilaku prososial dapat ditunjukkan dalam bentuk-bentuk sikap tertentu. Di sisi lain, perilaku prososial, merupakan tindakan yang menunjukkan hal sosial yang positif dan inklusif, termasuk kerjasama, berbagi, membantu, memberikan kepemimpinan, mengekspresikan empati, memberikan dukungan verbal atau dorongan, dan keramahan umum atau kebaikan (Rosen, 2010: 147). Dengan demikian, perilaku prososial merupakan perilaku menolong yang dapat ditunjukkan melalui berbagai macam bentuk.

Seperti kebanyakan perilaku lainnya, perilaku prososial memiliki faktor penentu baik faktor biologis maupun faktor lingkungan (Parke, 2009: 525). Kedua faktor tersebut sama-sama memiliki pengaruh yang besar dalam menentukan terjadinya perilaku prososial dalam diri seseorang.

Faktor lingkungan yang mempengaruhi perilaku prososial pada anak terbagi menjadi tiga jenis, yaitu anak-anak memiliki pengalaman dalam lingkungan sosial dari keluarga, teman sebaya, dan sekolah berperan dalam perilaku prososial mereka (Kostelnik, 2009: 454). Dengan kata lain, perilaku prososial dipengaruhi oleh lingkungan di sekitar anak.

Tahapan munculnya perilaku prososial pada anak meliputi tiga hal, yaitu kesadaran, keputusan, dan tindakan. Kostelnik mengungkapkan langkah-langkah untuk bertindak prososial meliputi (1) sadar bahwa berbagi, membantu, atau bekerja sama diperlukan, (2) memutuskan untuk bertindak, dan (3) melaksanakan perilaku prososial (Kostelnik, 2009). Ketiga tahapan tersebut harus dilalui oleh anak untuk akhirnya anak berperilaku prososial.

\section{Partisipasi Siswa Dalam Ekstrakurikuler Pramuka}

Partisipasi menurut asal katanya berasal dari serapan kosa kata bahasa Inggris, yaitu participation. Dalam kamus Oxford, partisipasi diartikan sebagai tindakan untuk berperan serta atau mengambil bagian dari suatu kegiatan. Dengan kata lain, partisipasi merupakan tindakan ikut serta dalam sebuah kegiatan.

Partisipasi merupakan suatu keterlibatan mental dan emosi seseorang kepada pencapaian tujuan dan ikut bertanggung jawab di dalamnya (Davis dalam wikipedia.org). Inti dari partisipasi adalah keterlibatan mental, emosi dan tanggung jawab seseorang dalam sebuah kegiatan.

Ekstrakurikuler merupakan istilah yang sering digunakan dalam dunia pendidikan. Dalam Peraturan Menteri Pendidikan Nasional No. 22 Tahun 2006 Tentang Standar Isi Untuk Satuan Pendidikan Dasar dan Menengah, ekstrakurikuler diartikan sebagai kegiatan pendidikan di luar mata pelajaran dan pelayanan konseling untuk membantu perkembangan peserta didik sesuai dengan kebutuhan, potensi, bakat dan minat melalui kegiatan yang secara khusus diselenggarakan oleh pendidik dan atau tenaga kependidikan yang berkemampuan dan berkewenangan di sekolah atau madrasah. Ekstrakurikuler memang ditunjukkan khusus untuk mengembangkan potensi peserta didik yang tidak didapat selama pembelajaran formal disekolah.

Pramuka atau praja muda karana adalah proses pendidikan di luar lingkungan sekolah dan keluarga dalam bentuk kegiatan yang menarik, menyenangkan, sehat, teratur, terarah, praktis, dan dilakukan dan dilakukan dialam terbuka dengan prinsip dasar kepramukaan dan metode kepramukaan yang sasaran terakhirnya adalah pembentukan watak, akhlak, dan budi pekerti luhur (Ilyas dan Qoni, 2012: 18). Dari pendapat tersebut dapat diketahui bahwa istilah pramuka kembali digunakan yang menunjuk pada pengertian dari gerakan pramuka atau kepramukaan.

Gerakan Pramuka sebagai organisasi kepanduan dilengkapi dengan prinsip dasar dan metode-metode yang dijadikan landasan dalam beraktivitas.Tiga dimensi dalam prinsip tersebut diperkuat oleh prinsip-prinsip dasar kepramukaan adalah yang terdiri dari: (1) iman dan taqwa kepada Tuhan Yang Maha Esa, (2) peduli terhadap bangsa dan tanah air, sesama dan alam beserta isinya, (3) peduli terhadap diri sendiri, serta (4) taat kepada kode kehormatan pramuka (Qorni dan Ilyas, 2012: 20). Ada satu yang menjadi tambahan dalam prinsip di atas adalah prinsip taat kepada kode kehormatan pramuka. Hal tersebut dimaksudkan bahwa dengan taan kepada kode kehormatan tersebutlah maka ada perbedaan yang mendasari Pramuka dengan gerakan atau organisasi yang lainnya.

Metode kepramukaan adalah kegiatan-kegiatan kepramukaan yang dikembangkan secara interaktif. Metode kepramukaan merupakan salah satu cara belajar interaktif progresif melalui: (1) pengamalan kode kehormatan pramuka, (2) belajar sambil melakukan, (3) sistem beregu, (4) kegiatan dialam terbuka yang menantang dan menarik serta mengandung pendidikan yang sesuai dengan perkembangan rohani dan jasmani, (5) kemitraan dengan anggota dewasa 
dalam setiap kegiatan, (6) sistem tanda kecakapan, (7) sistem satuan terpisah untuk putra dan putri, serta (8) kiasan dasar (Qoni dan Ilyas, 2012: 22). Dapat dikatakan bahwa kepramukaan memiliki metode yang berbeda dengan metode pendidikan pada umumnya. Metode kepramukaan menekankan pada kegiatan yang aktif dan berlangsung secara dua arah antara anggota dan juga Pembina.

Berdasarkan penjabaran diatas, dapat disimpulakan bahwa partisipasi siswa dalam ekstrakurikuler pramuka adalah tindakan ikut serta siswa dalam kegiatan kepramukaan yang diselenggaraan diluar jam pelajaran dengan metode dan prinsip-prinsip kepramukaan. Siswa dikatakan berpartisipasi dalam ekstrakurikuler pramuka apabila ada keterlibatan mental, emosi dan tanggung jawab didalam kegiatan kepramukaan. Jika tidak ada ketiga keterlibatan tersebut pada seseorang dalam kegiatan, maka orang tersebut dikatakan tidak berpartisipasi dalam ekstrakurikuler pramuka.

\section{METODE PENELITIAN}

Dilihat dari paradigma yang digunakan, penelitian ini termasuk dalam penelitian kuantitatif. Metode yang digunakan adalah expost facto karena variabel bebas dalam penelitian tidak diberi perlakuan tertentu dan tidak dikendalikan. Variabel bebas dalam penelitian adalah partisipasi dalam ekstrakurikuler pramuka siswa kelas III yang telah terjadi tanpa dimanipulasi oleh peneliti. Sedangkan variabel terikat yang menjadi akibat dari variabel bebas dalam penelitian ini adalah perilaku prososial siswa kelas III SD tersebut.

Populasi dalam penelitian ini adalah seluruh siswa kelas III Sekolah Dasar Negeri di Kelurahan Lubang Buaya, Jakarta Timur dengan sampel siswa kelas III SDN 09 Pagi dan SDN 11 Pagi Kelurahan Lubang Buaya, Jakarta Timur yang berjumlah 69 anak. Sampel diambil dengan menggunakan teknik pengambilan sampel cluster random sampling atau yang dapat diartikan pengambilan sampel berdasarkan unit yaitu sekolah. Penelitian dilaksanakan di SDN 09 Pagi dan SDN 11 Pagi Kelurahan Lubang Buaya, Jakarta Timur pada bulan Mei sampai dengan bulan Juni 2013.

Teknik pengumpulan data dalam penelitian ini difokuskan pada dua variabel penelitian, yaitu variabel bebas dan variabel terikat. Adapun variabel bebas (X) dalam penelitian ini yaitu partisipasi siswa dalam ekstrakurikuler pramuka. Variabel terikat $(\mathrm{Y})$ dalam penelitian ini yaitu perilaku prososial siswa kelas III Sekolah Dasar.

Instrumen yang digunakan untuk mengukur partisipasi siswa dalam ekstrakurikuler pramuka (variabel bebas) yaitu angket. Adapun kisi-kisi intstrumen partisipasi siswa dalam ekstrakurikuler pramuka yaitu sebagai berikut: (1) keterlibatan mental, meliputi keikutsertaan, kehadiran dan ketepatan waktu kehadiran siswa dalam mengikuti ekstrakurikuler pramuka di sekolah; (2) keterlibatan emosi, meliputi rasa bangga, rasa menyayangi, keantusiasan, serta keinginan untuk memajukan ekstrakurikuler pramuka disekolah; serta (3) tanggung jawab, meliputi penyelesaian tugas, kelengkapan atribut, serta penghafalan slogan atau yel-yel. Uji validitas untuk instrumen ini menggunakan uji Product Moment Pearson, sedangkan untuk uji reabilitasnya menggunakan uji Alpha Cronbach.

Setelah skor partisipasi siswa dalam ekstrakurikuler pramuka didapatkan dengan menggunakan angket, selanjutnya diurutkan dari skor siswa yang mendapatkan skor tertinggi sampai skor terendah dengan membuat tabel. Dari data tersebut, sampel akan dibagi menjadi dua kelompok, yaitu kelompok coba dan kelompok pembanding untuk diukur perilaku prososialnya. Kelompok coba merupakan kelompok siswa yang partisipasi dalam ekstrakurikuler pramukanya tinggi. Diambilnya jumlah siswa dalam kelompok ini berdasarkan perhitungan $27 \%$ skor tertinggi dari seluruh siswa yang dihitung partisipasinya dalam ekstrakurikuler pramuka. Kelompok pembanding merupakan kelompok siswa yang partisipasi dalam ekstrakurikuler pramukanya rendah. Diambilnya jumlah siswa dalam kelompok ini berdasarkan perhitungan $27 \%$ skor terendah dari seluruh siswa yang dihitung partisipasinya dalam ekstrakurikuler pramuka.

Instrumen yang digunakan untuk mengukur perilaku prososial siswa kelas III Sekolah dasar (variabel bebas) adalah observasi terstruktur. Kisi-kisi instrumen perilaku prososial siswa kelas III Sekolah Dasar meliputi: (1) menolong, (2) memberikan dukungan secara verbal, (3) berbagi, (4) bekerjasama, (5) menunjukkan empati, dan (6) keramahtamahan. Uji validitas untuk instrumen ini menggunakan uji Product Moment Pearson, sedangkan untuk uji reabilitasnya menggunakan uji Alpha Cronbach.

Teknik analisis data dalam penelitian ini menggunakan statistik deskriptif dan statistik inferensial. Statistik deskriptif dilakukan dengan 
mengelola data awal. Statistik deskriptif ini digunakan untuk mendeskripsikan data dengan melihat aspek rata-rata (mean), varian data dan modus data dalam penelitian.

Statistik inferensial digunakan untuk menganalisis data sampel dan hasilnya diberlakukan untuk populasi. Adapun statistik inferensial dalam penelitian ini meliputi uji normalitas yang digunakan untuk menguji normal atau tidaknya sebaran data pada kelompok penelitian yaitu kelompok coba (partisipasi siswa dalam ekstrakurikuler pramuka tinggi) dan kelompok pembanding (partisipasi siswa dalam ekstrakurikuler pramuka rendah). Uji normalitas pada penelitian ini menggunakan uji Liliefors. Setelah melakukan uji normalitas, selanjutnya dilakukan uji homogenitas, yaitu uji yang digunakan untuk mengetahui homogen atau tidaknya seragam atau tidaknya variansi-variansi variabel yang diambil dari populasi yang sama. Uji homogenitas dalam penelitian ini menggunaka uji Fisher.
Setelah kedua uji tersebut dilakukan, selanjutnya adalah menguji hipotesis statistik penelitian yang menguji ada atau tidaknya perbedaan antara dua buah mean sampel. Uji hipotesis dalam penelitian ini menggunakan uji-t yang dilakukan pada taraf signifikansi $\alpha=0,05$. Jika hipotesis nol $\left(\mathrm{H}_{0}\right)$ ditolak, maka perilaku prososial pada siswa yang partisipasi dalam ekstrakurikuler pramukanya tinggi, lebih tinggi dibanding perilaku prososial pada siswa yang partisipasi dalam ekstrakurikuler pramukanya rendah, yang berarti terdapat pengaruh partisipasi siswa dalam ekstrakurikuler pramuka terhadap perilaku prososial siswa kelas III SD. Namun, jika hipotesi nol $\left(\mathrm{H}_{0}\right)$ diterima maka perilaku prososial pada siswa yang partisipasi dalam ekstrakurikuler pramukanya tinggi, lebih rendah atau sama dibanding perilaku prososial pada siswa yang partisipasi dalam ekstrakurikulernya rendah, yang berarti tidak terdapat pengaruh partisipasi siswa dalam ekstrakurikuler pramuka terhadap perilaku prososial siswa kelas III SD.

\section{HASIL DAN PEMBAHASAN}

Berdasarkan deskriptif data dari perhitungan perilaku prososial pada kelompok coba dan kelompok pembanding siswa kelas III di SDN Lubang Buaya 09 dan 11 Pagi, dapat dilihat perbedaan yang signifikan antara dua kelompok tersebut. Hal itu dapat dilihat dari perbedaan nilai maksimum dan minimum, mean, median, modus, variaans dan standar deviasi dari data tersebut dalam bentuk tabel 1 berikut.

Tabel 1. Perhitungan Perilaku Prososial Kelompok Coba dan Pembanding

\begin{tabular}{|c|c|c|}
\hline $\begin{array}{c}\text { Keterangan Hasil } \\
\text { Data Perilaku } \\
\text { Prososial }\end{array}$ & \multicolumn{2}{|c|}{ Hasil Perhitungan } \\
\cline { 2 - 3 } & $\begin{array}{c}\text { Kelompok } \\
\text { Coba }\end{array}$ & $\begin{array}{c}\text { Kelompok } \\
\text { Pembanding }\end{array}$ \\
\hline Jumlah Responden & 20 & 20 \\
\hline Nilai Maksimum & 68 & 52 \\
\hline Nilai Minimum & 59 & 41 \\
\hline Mean & 63,2 & 46,4 \\
\hline Median & 64,5 & 44,5 \\
\hline Modus & 64 & 43,75 \\
\hline Varians & 5,536 & 12,568 \\
\hline Standar Deviasi & 2,353 & 3,545 \\
\hline
\end{tabular}

Berdsarkan tabel 1, masing-masing kelompok memiliki responden sebanyak 20 orang siswa. Pada kelompok coba diperoleh nilai maksimum sebesar 68 , nilai minimum 59 , nilai rata-rata 63,2 , nilai tengah 64,5 , nilai yang sering muncul 64 , besar varians 5,536 dan standar deviasi 2,353. Sedangkan pada kelompok coba diperoleh nilai maksimum 52, nilai minimum 41 , nilai rata-rata 46,4 nilai tengah 44,5 , nilai yang sering muncul 43,75, besar varians 12,568 dan standar deviasi 3,545 .

Data tersebut kemudian diolah untuk dianalisis melalui teknik analisis data. Teknik analisis data dalam penelitian ini menggunakan uji normalitas yaitu dengan uji Liliefors, uji homogenitas yaitu dengan uji Fisher dan uji hipotesis yaitu dengan uji-t. Hasil dari ketiga uji tersebut dapat dilihat dalam tabel 2 .

Tabel 2. Uji Persyaratan Analisis Data

\begin{tabular}{|c|c|c|c|c|}
\hline$\underset{\text { Uji }}{\text { Nama }}$ & $\begin{array}{c}\text { Uji Nor- } \\
\text { malitas } \\
\text { Kelom- } \\
\text { pok } \\
\text { Coba }\end{array}$ & $\begin{array}{c}\text { Uji Nor- } \\
\text { malitas } \\
\text { Kelompok } \\
\text { Pemband- } \\
\text { ing }\end{array}$ & $\begin{array}{l}\text { Uji Ho- } \\
\text { mogenitas }\end{array}$ & Uji-t \\
\hline & $\begin{array}{l}\mathrm{L}_{\text {hitung }}= \\
0,116\end{array}$ & $\begin{array}{l}\mathrm{L}_{\text {hitung }}= \\
0,150\end{array}$ & $\mathrm{~F}_{\text {hitung }}=2,165$ & $\begin{array}{l}\mathrm{Dk}=38 \\
\mathrm{t}_{\text {hitung }}=30,1\end{array}$ \\
\hline $\begin{array}{l}\text { Hasil } \\
\text { Pengu- } \\
\text { jian }\end{array}$ & $\begin{array}{l}\mathrm{L}_{\text {tabel }}= \\
0,190 \\
\text { Maka, } \\
\mathrm{L}_{\text {HIIUNG }}< \\
\mathrm{L}_{\text {TABEL }}\end{array}$ & $\begin{array}{l}\mathrm{L}_{\text {tabel }}=0,190 \\
\text { Maka, } \\
\mathrm{L}_{\text {hitung }}<\mathrm{L}_{\text {tabel }}\end{array}$ & $\begin{array}{l}\mathrm{F}_{\text {tabel }}=2,18 \\
\text { Maka, } \\
\mathrm{F}_{\text {hitung }}<\mathrm{F}_{\text {tabel }}\end{array}$ & $\begin{array}{l}D k=38 \\
t_{\text {hitung }}=30,1 \\
t_{\text {tabel }}=1,686 \\
\text { Maka, } \\
t_{\text {hitung }}>t_{\text {tabel }}\end{array}$ \\
\hline $\begin{array}{l}\text { Kesim- } \\
\text { pulan }\end{array}$ & $\begin{array}{c}\text { Data } \\
\text { pada } \\
\text { kelom- } \\
\text { pok coba } \\
\text { berdis- } \\
\text { tribusi } \\
\text { normal }\end{array}$ & $\begin{array}{l}\text { Data pada } \\
\text { kelom- } \\
\text { pok coba } \\
\text { berdistribu- } \\
\text { si normal }\end{array}$ & $\begin{array}{c}\text { Kedua } \\
\text { sampel } \\
\text { kelompok } \\
\text { penelitian } \\
\text { homogen }\end{array}$ & $\begin{array}{c}\mathrm{H}_{\mathrm{a}} \\
\text { diterima } \\
\mathrm{H}_{0} \text { ditolak }\end{array}$ \\
\hline
\end{tabular}


Berdasarkan tabel 2, diketahui pada uji normaliats data pada kelompok coba maupun kelompok pembanding berdistribusi normal, yang artinya jumlah data perilaku prososial pada kelompok coba dan pembanding pembanding yang bernilai ekstrim (terlalu rendah atau terlalu tinggi) tidak banyak. Selain itu, data berdistribusi normal juga memiliki arti bahwa jumlah data tersebut seimbang disisi kiri dan kananya. Hasil uji homogenitas menunjukkan antara sampel kelompok coba dan kelompok pembanding berasal dari populasi yang homogen.

Sedangkan pada uji hipotesis, diketahui hasil pengujian thitung sebesar 30,1 dan $t_{\text {tabel }}$ sebesar 1,686. Syarat $\mathrm{t}_{\text {hitung }}>\mathrm{t}_{\text {tabel }}$, membuktikan bahwa $\mathrm{H}_{0}$ (hipotesis nol) yang menyatakan bahwa tidak terdapat pengaruh signifikan dari partisipasi siswa dalam ekstrakurikuler pramuka terhadap perilaku prososial ditolak. Dengan demikian, $\mathrm{H}_{1}$ (hipotesis alternatif) yang menyatakan bahwa terdapat pengaruh signifikan dari partisipasi siswa dalam ekstrakurikuler pramuka terhadap perilaku prososial siswa kelas III SD diterima.

Berdasarkan hasil penelitian yang telah dilakukan, terdapat perbedaan antara perilaku prososial siswa yang partisipasi dalam ekstrakurikuler pramukanya tinggi (kelompok coba) dengan perilaku prososial siswa yang partisipasi dalam ekstrakurikuler pramukanya rendah (kelompok pembanding). Perilaku prososial siswa kelas III SD pada kelompok coba lebih tinggi dibanding kelompok pembanding. Dengan kata lain, siswa yang partisipasi dalam ekstrakurikuler pramukanya tinggi berpengaruh pada tingginya perilaku prososial siswa tersebut.

Bentuk keramahtamahan dalam perilaku prososial merupakan skor yang paling tinggi yang ditunjukkan oleh siswa dalam kelompok coba. Siswa menunjukkan tindakan untuk berteman dengan siapa saja (tidak pilih teman). Mereka juga terbiasa untuk menyapa teman ketika bertemu di dalam kelas ataupun saat berada di luar kelas selama disekolah. Pada kelompok pembanding, skor yang diperoleh tidak berbeda jauh, hanya saja frekuensi kemunculannya belum konsisten seperti kelompok coba. Bentuk keramahtamahan menjadi skor tertinggi pada bentuk tindakan perilaku prososial dalam kelompok coba dikarenakan setiap kegiatan ekstrakurikuler pramuka berlangsung, pembina selalu mengajak para siswa untuk duduk melingkar. Dalam posisi tersebut, masingmasing siswa diminta untuk saling menyapa siswa lain satu per satu dengan menyebutkan namanya, sehingga siswa lebih mengenal siswa lain dan menjadi lebih akrab.

Bentuk dari perilaku prososial lain yang mendapatkan skor tertinggi dari kelompok coba, yaitu tindakan memberikan dorongan secara verbal. Siswa pada kelompok coba menunjukkan tindakan tersebut dengan jelas pada saat kesempatan dalam kegiatan di luar ruangan, yaitu saat kegiatan olahraga dan juga pada saat kegiatan ekstrakurikuler pramuka berlangsung. Tindakan tersebut juga dilakukan secara konsisten, yang perbedaannya terlihat pada kelompok pembanding, pada kelompok ini tindakan tersebut sering pula dilakukan hanya belum konsisten seperti kelompok coba.

Pada bentuk tindakan menolong, kelompok coba juga mendapatkan skor rata-rata tertinggi. Hal ini terlihat dari tindakan menolong siswa yang konsisten terhadap siswa lainnya. Tindakan tersebut terlihat pada saat siswa berada di dalam kelas maupun di luar kelas. Siswa pada kelompok pembanding juga menunjukkan hal yang sama, hanya saja frekuensinya sebesar $5 \%$ pada tingkat kemunculan selalu dan kemunculan tindakan tersebut belum konsisten seperti halnya kelompok coba.

Bentuk tindakan berbagi dalam perilaku prososial antara kelompok coba dan pembanding sama-sama menunjukkan skor rata-rata pada frekuensi kemunculan tinggi. Hampir seluruh siswa menunjukkan tindakan tersebut dengan memberikan sumbangan pada kegiatan hari amal. Namun yang membedakan kemunculan antara kelompok coba dan pembanding adalah tindakan berbagi yang dilakukan siswa terhadap siswa yang lainnya, siswa dalam kelompok coba menunjukkan tindakan ini konsisten.

Pada bentuk tindakan bekerja sama, skor tertinggi ditunjukkan oleh kelompok coba. Hal ini paling terlihat pada saat kegiatan kelompok berlangsung, yaitu saat kegiatan ekstrakurikuler pramuka. Siswa pada kelompok coba menunjukkan tindakan menerima siswa lain yang akan menjadi teman kelompoknya. Selain itu, siswa juga melakukan tindakan memberikan saran atau masukan pada saat kegiatan kelompok tersebut. Hal ini kurang terlihat pada kelompok pembanding karena pada kelompok pembanding siswa jarang terlibat dalam kegiatan kelompok.

Bentuk tindakan mengekspresikan empati merupakan bentuk tindakan perilaku prososial dengan skor terendah pada kelompok coba. Skor yang diperoleh oleh kelompok coba adalah sebesar $63,7 \%$ pada frekuensi kemunculan selalu. Hal tersebut dikarenakan tindakan mengekspresikan empati cenderung sulit untuk diamati karena kemunculannya hanya ada pada saat-saat tertentu, seperti ketika ada teman yang sedang sedih. Jadi kemungkinan untuk mengamati kemunculan tindakan ini lebih 
kecil dibanding mengamati tindakan-tindakan lain dari perilaku prososial pada kelompok coba maupun kelompok pembanding.

Berdasarkan penjabaran di atas, bentuk-bentuk dari perilaku prososial muncul lebih tinggi pada kelompok coba dibandingkan kelompok pembanding. Partisipasi siswa dalam ekstrakurikuler pramuka terlihat memberikan pengaruh terhadap perilaku prososial siswa. Ekstrakurikuler pramuka menjadi sebuah lingkungan sosial yang mendukung siswa dalam berperilaku prososial. Hal tersebut sesuai dengan pendapat Parke bahwa perilaku prososial memiliki faktor penentu baik faktor biologis maupun faktor lingkungan, yang dalam hal ini lingkungan tersebut adalah ekstrakurikuler pramuka. Ekstrakurikuler pramuka merupakan lingkungan yang memberikan kesempatan bagi siswa untuk mengembangkan perilaku prososial. Dalam ekstrakurikuler pramuka, siswa dilibatkan dalam kegiatan-kegiatan yang merangsang timbulnya perilaku prososial, seperti berkemah dan bakti sosial. Pengamalan janji pramuka yaitu Dasadarma yang berisi pernyataan anggota pramuka untuk menjalankan bentuk perilaku prososial juga merupakan contoh yang lainnya.

Partisipasi siswa dalam ekstrakurikuler pramuka memberikan kesempatan bagi siswa untuk lebih dekat dengan teman sebaya sesama anggota pramuka yang lainnya. Pendapat yang diungkapkan oleh Kostelnik bahwa teman sebaya merupakan salah satu yang memegang peranan dalam mendorong perilaku prososial, terlihat ketika siswa melakukan kegiatan bersama-sama. Hal tersebut sesuai dengan sistem yang digunakan adalam sistem beregu dimana setiap kegiatan harus dilakukan secara bersama-sama. Dengan demikian, kemungkinan untuk siswa lebih berperilaku prososial semakin besar.

Keterkaitan antara partisipasi siswa dalam ekstrakurikuler pramuka terhadap perilaku prososial secara garis besar dapat dijelaskan dengan mengacu pada teori yang diungkapkan oleh Kostelnik (2009: 454) bahwa perilaku prososial dipengaruhi oleh pengalaman mengamati perilaku prososial, pengalaman melakukan kebaikan, dan juga pengalaman mendapatkan reaksi dari usaha diri untuk menjadi pribadi yang prososial. Faktor-faktor yang mendorong perilaku prososial tersebut dapat ditemukan dalam ekstrakurikuler pramuka, seperti yang telah dijabarkan pada paragrafparagraf sebelumnya. Hal tersebut dipertegas dengan hasil penelitian yang lilihat dalam uji-t dimana kesimpulan yang didapat menyatakan terdapat perbedaan antara dua kelompok coba dan kelompok pembanding, yang berarti bahwa terdapat pengaruh signifikan partisipasi siswa dalam ekstrakurikuler pramuka terhadap perilaku prososial siswa kelas III SD.

\section{PENUTUP}

Penelitian ini melihat pengaruh partisipasi siswa dalam ekstrakurikuler pramuka terhadap perilaku prososial siswa kelas III Sekolah Dasar. Perilaku prososial menjadi topik yang banyak diteliti beberapa tahun terakhir. Perilaku prososial pada siswa sekolah dasar khususnya mengalami kemerosotan atau penurunan. Perilaku prososial siswa diharapkan dapat didorong agar meningkat melalu partisipasi siswa dalam ekstrakurikuler pramuka. Terlebih ekstrakurikuler pramuka pada tahun ini dicanangkan sebagai ekstrakurikuler wajib yang diselenggarakan di sekolah dasar. Partisipasi siswa dalam ekstrakurikuler pramuka syarat akan kegiatan-kegiatan yang dapat membantu mengembangkan perilaku prososial siswa. Dengan siswa berpartisipasi dalam ekstrakurikuler pramuka diharapkan dapat membantu munculnya perilaku prososial pada siswa itu sendiri.
Berdasarkan perhitungan uji-t menunjukkan $t_{\text {hitung }}>t_{\text {tabel }}$ yang berarti bahwa $\mathrm{H}_{0}$ (hipotesis nol) yang menyatakan bahwa perilaku prososial siswa yang partisipasi dalam ekstrakurikuler pramukanya rendah, lebih tinggi atau sama dengan perilaku prososial pada siswa yang partisipasi dalam ekstrakurikuler pramukanya tinggi, yang berarti tidak terdapat pengaruh yang signifikan partisipasi siswa dalam ekstrakurikuler pramuka terhadap perilaku prososial siswa kelas III SD ditolak. Dengan demikian $\mathrm{H}_{1}$ diterima yang dapat disimpulkan bahwa perilaku prososial siswa yang partisipasi dalam ekstrakurikuler pramukanya tinggi, lebih tinggi dibanding perilaku prososial pada siswa yang partisipasi dalam ekstrakurikuler pramukanya rendah. Oleh karena itu, apabila siswa lebih berpartisipasi dalam ekstrakurikuler pramuka maka dapat meningkatkan perilaku prososialnya. 


\section{DAFTAR PUSTAKA}

Desmita. (2009). Psikologi perkembangan peserta didik. Bandung: PT Remaja Rosdakarya.

Ilyas,.\& Qoni. (2012). Buku pintar pramuka. Yogyakarta: Familia.

Knafo, A. et.al. (2005). "Prosocial behavior from early to middle childhood". Journal of Developmental Psychology: Vol. 42 No 5.

Kostelnik, M.J. (2009). Guilding children's social development \& learning 6th edition. New York: Delmar Cengange Learning.

Maria. et.al. (2005). "Prosocial behavior in context". Journal of university of nebraska-lincoln. Diakses tanggal 23 Januari 2013 dari http://digitalcommons.unl.id
Parke, R.D. (2009). Child physicology 7th edition. New York: Mc. Graw- Hill.

Puckett. M.B. et.al. (2004). Teaching young children. Canada: Delmar Learning.

Rossen. J.A. et.al. (2010). Noncognitive skills in the classroom. RTI Press.

http://ogimeita85.wordpress.com/2013/01/15/uaslandasan-problematika-pendidikan-2013/

http://oxforddictionaries.com/definition/english/participation

http://id.wikipedia.org/wiki/Partisipasi 